UDC (338.48-043.86):005.591.452

DOI https://doi.org/10.32838/TNU-2663-5941/2020.6-2/15

Rohova N.V.

Higher Educational Establishment of Ukoopspilka "Poltava University of Economics and Trade"

Volodko O.V.

Higher Educational Establishment of Ukoopspilka "Poltava University of Economics and Trade"

\title{
NUTRITIONAL AND BIOLOGICAL VALUE OF JUICES, THEIR EFFECT ON THE HUMAN BODY AND THEIR IMPORTANCE IN NUTRITION
}

The strategy of expanding the range of products useful for human health as a priority for the development of the food industry of Ukraine is due to the need to preserve the health of the population and improve the quality of life. Modern trends in the development of hotel and restaurant services, travel services also require a range of biologically active products with a long shelf life to develop certain diets and diets.

Scientific substantiation and development of modern technologies of production of high-quality low-calorie and inexpensive products from ecologically pure domestic raw materials and their introduction is one of the main directions of development of modern branches of food science. At the same time, the search for new effective technologies for the manufacture of modern products from plant raw materials and the preservation of its natural properties remains an urgent problem.

The main direction of the food industry development should be investigation on a scientific basis and the introduction into production of high quality and inexpensive food products. The way out is to use environmentally friendly raw materials grown nearby canneries, as well as to use modern technologies for its transformation. Among the foods that have protective functions, juices are of paramount importance. Although juices are not completely free of mutagens, antimutagenic activity is predominant. So far there is not enough complete information about the tread mechanisms of juices.

In terms of mass production and consumption, beverages occupy a leading place in the diet. According to numerous studies in the field of nutrition physiology, the most rational form of them are soft drinks, the biochemical and microbiological composition of which largely depends on the health of the population. Therefore, the problem of creating and producing soft drinks for general health purposes has an exceptional impact on the preservation of the nation's gene pool and the development of food and processing industries.

Key words: technology, birch sap, nutrition, vitamins, aromatic and mineral substances.

Formulation of the problem. The production and consumption of juices takes into account the presence of easily digestible carbohydrates, acids, aromatic and mineral substances, vitamins, etc. Juices are easily digestible products that have stimulating, strengthening, antitoxic and diuretic properties. Juices are a source of moisture, which is necessary for human life, but also provide the human body with nutrients and biologically active substances (BAS): carbohydrates, organic acids, aromatic and mineral substances, vitamins and others.

The strategy of expanding the range of products useful for human health as a priority for the development of the Ukrainian food industry is due to the need to preserve the health of the population and improve the quality of life. Modern trends in the development of hotel and restaurant services, travel services also require a range of biologically active products with a long shelf life to develop certain diets and diets. Scientific substantiation and development of modern technologies of production of high-quality low-calorie and inexpensive products from ecologically pure domestic raw materials and their introduction is one of the main directions of development of modern branches of food science.

Analysis of recent research publications. The strategy of expanding the range of products useful for human health as a priority for the development of the Ukrainian food industry is due to the need to preserve the health of the population and improve the quality of life. Modern trends in the development of hotel and restaurant services, travel services also require a range of biologically active products with a long shelf life to develop certain diets and diets. Scientific substantiation and development of modern technologies of production of high-quality lowcalorie and inexpensive products from ecologically pure domestic raw materials and their introduction is one of the main directions of development of modern branches of food science.

At the same time, the search for new effective technologies for the manufacture of modern products 
from plant raw materials and the preservation of its natural properties remains an urgent problem.

Formulation article goals. The range of low-calorie juices and beverages in Ukraine, which are able to correct the negative impact of environmental and pathogenic factors and increase the level of consumption of biologically active and radioprotective compounds is not enough. In addition, as the monitoring of the market of juices and beverages proves, there are practically no microbiota of the human gastrointestinal tract enriched with the products of life of lactic acid bacteria-normalizers products of this range.

Therefore, it is advisable to expand the range of juices and beverages that are easily digestible products that have stimulating, strengthening, antitoxic and diuretic properties. The production and consumption of juices takes into account the presence of easily digestible carbohydrates, acids, aromatic and mineral substances, vitamins, etc. Juices are easily digestible products that have stimulating, strengthening, antitoxic and diuretic properties.

Juices are a source of moisture, which is necessary for human life, provide the human body with nutrients and biologically active substances (BAS): carbohydrates, organic acids, aromatic and mineral substances, vitamins and others.

The human body contains $60 \%$ of water, and some organs, the human brain for instance, contain up to $85 \%$ water. With considerable physical exercise or the disease, each person during the day loses from 2.5 to $8 \mathrm{dm}$ протягом of water. The loss of $10 \%$ of water, which is part of the human body, leads to fatal consequences. The role of water in the body is mainly as follows:

1) lethal outcome;

2) maintain the temperature of the human body;

3) dissolves food nutrients and transports them to the cells, where they are digested and then transfers the final metabolic products to the kidneys, skin, lungs, etc., which secrete them;

4) dissolves minerals and carries out their movement in the body, providing a metabolic effect.

Water losses must be compensated by water, juices and various beverages. Water from natural sources undergoes a number of operations and treatments, and may not always be pleasant to the taste.

In order to meet human needs for drinking water, mineral waters are bottled. The amount of mineral water that can be bottled meets a person's need for drinking water only to a small extent. Therefore, attempts are being made to partially replace it with products that contain a large amount of water and have a pleasant taste. At the same time, the goal of introducing into the human body certain substances necessary for a balanced diet and human health is achieved [1]. Juices are products that can to some extent replace water, and also serve the above purposes.

Presenting main material. Birch sap is obtained from the most common birch species in Ukraine. The range of applications of birch sap is quite wide. In addition to the food industry, birch sap has been found to be a raw material for edible fat. Turbidity of the sap at the end of sap production is accompanied by the formation of foam on the grooves and in the channels of leaked trees. Especially a lot of foam on fresh birch stumps. To the touch, it resembles a fat mass.

Academician GA Nadson at the beginning of the last century [2] studied the possibility of cultivating yeast-like fungi on birch sap. Lipid yield reached $28 \%$ of the dry matter of fungi. In recent decades, birch sap is used for the production of lotions, shampoos, birch eau de toilette. Due to the content of betulin in birch sap, cosmetics made from it have healing and refreshing properties. In the laboratory of the Moscow perfume factory "Dawn" from birch sap created lotion "Birch", which was highly praised by experts. The composition of the lotion "Birch" includes 30\% natural birch sap and 35\% ethyl alcohol and glycerin [3].

In some European countries birch sap is harvested and processed by industrial methods to obtain cosmetics. In the Czech Republic, freshly harvested birch sap is preserved by adding $10 \%$ ethyl alcohol. This product is used to make the famous birch water, birch cream and hair shampoo, the demand for which is growing from year to year. Observations by the Sverdlovsk Forest Chemical Research Station show that cows and calves are willing to drink birch sap. This sharply reduces the incidence of calves [4]. Agricultural societies located near birch forests should organize the collection of sap for livestock needs.

Experiments of germination in birch sap of seeds of a number of vegetable and grain crops have given positive results. Usually the means for germination of grains in the laboratory are solutions of sucrose and glucose in equal concentrations. Sometimes gelatin or agar-agar is added to the nutrient solution to accelerate the germination of pollen grains. It is established that birch sap contains all the substances necessary for pollen germination. Within an hour after sowing in birch sap, most pollen grains germinate.

In the scientific and technical literature there is evidence of the use of birch sap as an effective food for bees. It has been established that feeding bees with ordinary sugar syrup causes a decrease in the quality of honey. This is primarily due to the fact that beet sugar 
contains mainly sucrose. Birch sap consists of glucose and fructose - the main components of honey. From the above it can be seen that birch sap is a valuable food and raw material for various industries. Due to the results of research in Japan, Russia, Ukraine in recent years a significant place is given to betuloprenols and their derivatives, important therapeutic factors of birch sap. However, fresh juice is stored for only 2-3 days and only under certain temperature conditions. Due to the development of spontaneous microbiota, there is a fermentation of freshly harvested sap and its non-compliance with the requirements of birch sap standards, so it needs to be processed.

Properties of fermented juices and beverages. Non-alcoholic fermented juices and beverages are substrates of plant origin, organoleptic and physicochemical properties of which are formed as a result of the activity of cultures of microorganisms, and the ethanol content does not exceed $1.2 \%$ of the mass. The most widespread are drinks, the technology of which involves the use of lactic acid bacteria.

The antagonistic properties of lactic acid bacteria to the putrefactive microflora of the intestinal tract were first proved by I.I. Swordsmen. He believed that the absorption of the products of life of putrefactive microbes living in the intestinal tract, poisons the human body and causes premature aging. To combat premature aging, II Mechnikov recommended the systematic use of fermented milk products made using lactic acid bacteria [5].

The inhibitory effect of lactic acid bacteria on other microorganisms is due to various factors. Thus, in the first works on the antagonism of lactic acid bacteria, the main factor was considered to be lactic acid secreted by bacteria. It increases the acidity of the environment and inhibits the development of putrefactive microorganisms. In addition to organic acids, other substances produced by lactic acid bacteria during growth are also involved in the mechanism of inhibition. The works of M.L. Gorbunova, A.Z. Arkhipova showed that the active effect on infectious agents is caused by hydrogen peroxide, which is also produced by coccal and rod-shaped lactic acid microorganisms. The antagonistic effect of lactic acid bacteria is manifested in the competition for nutrients. Lactic acid microorganisms produce antimicrobial substances, in particular nisin and the like.

Recently, there is evidence of a positive effect of lactic acid bacteria on radiation exposure. It is believed that they promote the excretion of radionuclides [8]. It has also been established that lactic acid bacteria are effective in the treatment of human dysbacteriosis, the development of which is facilitated by the widespread use of antibiotics and chemicals in medical practice. This reduces the content of beneficial microorganisms and increases the number of Escherichia coli with altered properties, bacteria of the proteus group, spore microflora, etc. All this contributes to intestinal dysfunction and the development of diseases such as choleenteritis, dysentery, food poisoning.

Non-alcoholic fermented juices and beverages are products of plant origin, organoleptic and physicochemical properties of which are formed as a result of the activity of cultures of microorganisms, and the ethanol content does not exceed $1.2 \%$ of the mass. The most widespread are drinks, the technology of which involves the use of lactic acid bacteria.

Composition, biological value of deciduous tree sap. The value and usefulness of the sap of deciduous trees is determined by its properties and composition. Depending on the calendar time of sap production and the diameter of trees, the relative density of birch sap varies in the range of 1,0007-1,0038, maple - in the range of 1,0021-1,0046 g/cm3. During the calendar time of swapping, there is a change in relative density: it increases in the first half of the swoop and decreases in the second. As the diameter of the trees increases, the relative density of the sap increases. According to Telishevsky DO, Orlova II relative density of birch sap is about $1.0030 \mathrm{~g} / \mathrm{cm} 3$, and Korolyak IS and Tomchuk RI [6] found that this figure varies from 1,0029 to $1.0046 \mathrm{~g} / \mathrm{cm} 3$. The dry matter content in the juice of warty birch, maple and sycamore for a number of regions of our country is given in table 1 .

The difference in dry matter content is primarily due to growth conditions, tree diameter, sampling time during the calendar period of pruning and other factors. As the diameter of trees or stumps increases, there is usually a tendency to increase the dry matter content in the sap. In some cases, birch is characterized by a more intense increase in dry matter content in the first half of pruning and less sharp decrease, but in the second half. In other cases, due to a sharp rise in air temperature in the second half of the juicing with a relatively high dry matter content stops [7]. Juicing of maple and sycamore, is discrete [8]. The quality of the juice largely depends on its sugar content. Data on the content of sugars in the sap of deciduous trees are given in table 2 .

The table shows that the highest sugar content is the juice of maple, then maple and only then - birch. In addition, birch sap contains a significant amount of glucose and fructose, which are well absorbed by the body. There is a tendency to increase the sugar content of the sap with increasing diameter of trees. 
The average content of sugars in the sap of trees with different diameters and sizes of crowns differs by about $0.1 \%$ [9].

The sugar content of the juice also depends on the origin of the birch trees. Thus, in coppice birches the sugar content in the first half of the pruning season was $1.05 \%$, and in the second $0.7-1.0 \%$, in birches of seed origin, respectively, 1.1 and $0.5 \%$. There was no significant difference in the sugar content of day and night juices, only on some days there is a slight increase in the sugar content of day juice [9]. The sugar content of the sap is also significantly affected by the type of forest vegetation conditions. As follows from the data of Egorenkov M.A., Gunyazhenko I.V. [10], the sugar content of birch sap depends on forest types. The highest sugar content was observed in the dreamy type of forest $(1.64 \%)$, slightly lower in nettle $(1.30 \%)$ and eagle $(1.26-1.31 \%)$, the lowest in heather birch with a small amount of birch.
Thus, it is most expedient to conduct industrial pruning in relatively rich in sugar types of birch trees - snipe, honeysuckle and nettle. Single trees of maple, growing in identical conditions, have a sugar content of 2 to $2.9 \%$. It is established that the content of sugars in the juice is not constant over the years. For the conditions of Ukraine, the offseason variability of the sugar content is illustrated in table 3.

The data in table 3 show significant fluctuations in the sugar content of the juice over the years of pruning. Quite valuable is the fact that when re-counting the decrease in sugar content is not observed. The content of sugars in birch and maple sap changes during the calendar time of pruning. In the first half of podsochki increase in sugar content of juice is observed, in the second - decrease. The active acidity of birch, maple and maple sap is characterized by the data given in table 4 .

Table 1

Dry matter content in the sap of deciduous trees

\begin{tabular}{|c|c|c|c|}
\hline The object of the search & Surveillance area & Average diameter, $\mathbf{~ m m}$ & Dry matter content, $\%$ \\
\hline \multirow{3}{*}{ Warty birch, trees } & Volyn region & 300 & $0,86-0,90$ \\
\cline { 2 - 4 } & Lviv region & 300 & $0,89-1,49$ \\
\cline { 2 - 4 } & Poltava region & 300 & $0,85-0,95$ \\
\hline \multirow{2}{*}{ Warty birch, hemp } & Lviv region & 489 & $1,18-1,32$ \\
\cline { 2 - 4 } & Poltava region & 490 & $0,97-1,15$ \\
\hline \multirow{2}{*}{ Maple sharp-leaved, trees } & Lviv region & 410 & $1,54-2,92$ \\
\cline { 2 - 4 } & Poltava region & 407 & $1,65-2,84$ \\
\hline \multirow{2}{*}{ Maple, trees } & Lviv region & 358 & $1,0-3,3$ \\
\cline { 2 - 4 } & Poltava region & 360 & 1 \\
\hline
\end{tabular}

Table 2

Sugar content in deciduous sap depending on the region of cultivation

\begin{tabular}{|c|c|c|c|c|c|}
\hline \multirow{2}{*}{ Breed } & \multirow{2}{*}{ Surveillance area } & \multicolumn{4}{|c|}{ Sugar content, \% } \\
\cline { 3 - 6 } & Volyn region & general & saccharose & glucose & fructose \\
\hline \multirow{3}{*}{ Warty birch } & Lviv region & $0,58-0,86$ & - & 0,50 & 0,36 \\
\cline { 2 - 6 } & Chmelnytsk region & $0,86-1,41$ & $0,59-0,15$ & $0,32-0,74$ & $0,51-0,58$ \\
\cline { 2 - 6 } & Poltava region & $0,76-0,86$ & - & $0,27-0,68$ & $0,49-0,18$ \\
\hline Maple sharp-leaved & Lviv region & $0,04-0,72$ & - & $0,02-0,11$ & $0,02-0,61$ \\
\hline $\begin{array}{c}\text { Maple } \\
\text { Клен-явip }\end{array}$ & & $1,46-1,71$ & - & $0,09-0,84$ & $0,03-0,43$ \\
\hline
\end{tabular}

Table 3

Variability of sugar content of birch sap over the years of pruning

\begin{tabular}{|c|c|c|c|c|c|c|}
\hline \multirow{2}{*}{ Surveillance area } & \multirow{2}{*}{$\begin{array}{c}\text { Average } \\
\text { diameter, mm }\end{array}$} & \multicolumn{3}{|c|}{ Sugar content over the years of pruning, \% } & $\begin{array}{c}\text { Average sugar } \\
\text { content, \% }\end{array}$ \\
\cline { 3 - 7 } & & First & Second & Third & Fourth & \\
\hline Lviv region & 22,0 & 0,90 & 0,92 & 1,08 & 0,70 & 0,90 \\
\hline Rivne region & 21,0 & 0,86 & 0,89 & 1,05 & 0,67 & 0,86 \\
\hline Poltava region & 20,0 & 0,82 & 0,84 & 1,03 & 0,62 & 0,82 \\
\hline
\end{tabular}


From these data it is seen that in comparison with maple and maple sap birch sap has a higher active acidity. During the calendar time, as established by Ryabchuk V.P., Osipenko Y.F., there is a clear pattern of juicing, which consists in increasing the acidic environment of the juice to the end of the suction. Thus, in all cases, the juice forms an acidic environment. A number of organic acids were found in the sap of deciduous trees. The total acid content in terms of malic is characterized by the data given in table 5 .

As can be seen from these data, the maximum content of titratable acids is the juice of maple $(0.159 \%)$, the minimum - maple juice $(0.004 \%)$. In particular, $0.25 \mathrm{mg} / 100 \mathrm{~g}$ of organic acids and $1.3 \mathrm{mg} / 100 \mathrm{~g}$ of ascorbic acid were found in the juice of maple; maple sap, respectively -0.24 and $1.07 \mathrm{mg} / 100 \mathrm{~g}$. The sap of deciduous trees contains nicotine, pantothenic, glutamine. Along with organic substances, the juice contains minerals. Their content depends on the breed, growing conditions of the tree,

Table 4

Active acidity of birch, maple sap

\begin{tabular}{|c|c|}
\hline Types of the trees & $\begin{array}{c}\text { Active acidity of the juice, } \\
\mathbf{\%}, \mathbf{p H}\end{array}$ \\
\hline Warty birch & $5,2-6,5$ \\
\hline Maple sharp-leaved & $6,2-7,0$ \\
\hline Maple & $6,1-6,9$ \\
\hline
\end{tabular}

the time of sampling the sap during the pruning period and a number of other factors.

The ash content of birch, maple and maple sap, expressed in $\mathrm{mg} / 100 \mathrm{~g}$, for some regions of the country is shown in table 6 [10].

The ash content in birch sap varies significantly depending on the type of forest vegetation conditions. The content of ash in maple juice is slightly higher than in maplejuice. The ash of the sap of deciduous trees includes a number of chemical elements. Analysis of birch and maple sap, conducted by Ryabchuk V.P. and Osipenko Y.F., found a number of chemical elements (table 7).

From the data in table 7 it follows that in the ash sap of the above trees is dominated by potassium. The chemical elements that make up birch and maple sap are an integral part of the fluid, tissues and bones of the human body. They are necessary for the normal functioning of the body and metabolism. For example, calcium is involved in metabolism, is part of the bones, reduces the excitability of the nervous system in muscle tissue, is also necessary for blood coagulation.

If we compare the mineral composition of such wellknown canned juices as apple and tomato, the individual trace elements of birch and maple juices exceed them several times. For example, the content of manganese birch canned juice is 3.5 times higher than apple unclarified. Canned maple juice contains 11 times more copper than unclarified apple juice and 5.5 times more

Table 5

The total acid content in the sap of trees of different species

\begin{tabular}{|c|c|}
\hline Types of the trees & The total acid content (in terms of malic), $\%$ \\
\hline Warty birch & 0,01 \\
\hline Volyn region & 0,02 \\
\hline Lviv region & 0,01 \\
\hline Poltava region & 0,16 \\
\hline Maple sharp-leaved & 0,01 \\
\hline Maple & \\
\hline
\end{tabular}

Table 6

Ash content of deciduous tree sap

\begin{tabular}{|c|c|c|c|c|}
\hline \multirow{2}{*}{ Types of the trees } & Surveillance area & $\begin{array}{c}\text { Average } \\
\text { diameter, mm }\end{array}$ & $\begin{array}{c}\text { Type of forest } \\
\text { vegetation conditions }\end{array}$ & $\begin{array}{c}\text { The ash content of } \\
\text { the juice, } \mathbf{M} \mathbf{1} \mathbf{1 0 0} \mathbf{\Gamma}\end{array}$ \\
\hline \multirow{3}{*}{ Warty birch } & Khmelnytskiy region & 290 & 32 & 0,0393 \\
\cline { 2 - 5 } & Lviv region & 300 & 33 & 0,0621 \\
\cline { 2 - 5 } & Poltava region & 310 & 33 & 0,0355 \\
\hline \multirow{2}{*}{ Maple sharp-leaved } & Lviv region & 420 & 32 & 0,0438 \\
\cline { 2 - 5 } & Poltava region & 400 & 32 & 0,0280 \\
\hline \multirow{3}{*}{ Maple } & Ternopil region & 320 & 33 & 0,0274 \\
\cline { 2 - 5 } & Lviv region & 300 & 32 & 0,0425 \\
\cline { 2 - 5 } & Poltava region & 310 & 32 & 0,0263 \\
\hline
\end{tabular}


Table 7 than tomato juice. Some of them, such as copper, cobalt, The chemical composition of the ash of the sap zinc, iron, nickel, in one form or another are involved in of deciduous trees, $\mathrm{mg} / 100 \mathrm{~g}$

\begin{tabular}{|c|c|c|}
\hline $\begin{array}{c}\text { Name of chemical } \\
\text { elements }\end{array}$ & $\begin{array}{c}\text { Maple } \\
\text { sharp-leaved }\end{array}$ & $\begin{array}{c}\text { Warty } \\
\text { birch }\end{array}$ \\
\hline potassium (kalium) & 230,00 & 0.273 \\
\hline phosphorus & 2,51 & 0.025 \\
\hline sodium (natrium) & 17,00 & 2.00 \\
\hline calcium & 13,87 & 13,33 \\
\hline aluminium & 6,01 & 1,82 \\
\hline nitrogen & 4,90 & traces \\
\hline magnesium & 4,81 & 6.08 \\
\hline manganese & 1,21 & 1,15 \\
\hline silicon & 0,83 & 1,10 \\
\hline strontium & 0,18 & 0,02 \\
\hline titanium & 0,11 & 0,08 \\
\hline iron (ferrum) & 0,07 & 0,15 \\
\hline barium & 0,06 & 0,01 \\
\hline zirconium & 0,01 & 0,01 \\
\hline lanthanium & 0,01 & 0,01 \\
\hline nickel & traces & 0,01 \\
\hline copper (cuprum) & traces & 0,63 \\
\hline
\end{tabular}
the activation of enzymes. In addition to these chemical compounds and elements in the composition of birch sap include [10]: essential oils, betulol (white resinous substance that fills the cavities of cortical tissue cells on birch trunks and gives it a white color), saponin compounds, cytokinins, biotin, thiamine, pyridoxine. Studies have shown that the amount of minerals in the juice gradually increases and at the end of the juicing phase reaches its maximum value.

Conclusions. Therefore, juices fermented with lactic acid bacteria are also useful in human nutrition. The chemical composition of birch and sap of other deciduous trees explains the desire of the population to consume them as thirst-quenching, vitamin and even health drinks.

Thus, the use of fermented beverages, the technology of which is based on the metabolism of lactic acid bacteria, is able to regulate the processes associated with the disruption of the intestinal microflora and has a general health effect on the human body.

\section{References:}

1. Rogova N.V. Manufacture technology of fermented birch sap and new combined products based. Actual problems of the world today : Materials of collective monograph / Rogova N.V., Volodko O.V. London, 2019. P. 252-267.

2. Рогова Н.В., Кожухар В.В., Пилипенко Л.М., Паулина Я.Б. Дослідження біологічної активності ферментованого березового соку. Вісник ХНТУСГ ім. П. Василенко "Сучасні напрями технології та механізаuіï прочесів переробних і харчових виробнищтв». 2006. Вип. 45. С. 371-376.

3. Рогова Н.В., Володько О.В., Бичков Я.М., Рибакова С.С. Харчова біологічна цінність соків, їх дія на організм людини та значення в харчуванні. Science and society: 9th Intern. conf. (Hamilton, Canada, 1st February, 2019). Hamilton, 2019. P. 95-98.

4. Банникова Л.А., Королева Н.С., Семенихина В.Ф. Микробиологические основы молочного производства : справочник. М. : Агропромиздат, 1987. 285 с.

5. Технологія екстратів, концентратів і напоїв із рослинної сировини /за ред. Домарецького. Вінниця : Нова книга, 2005. 408 с.

6. Данилов Н.И. Чудо - целитель береза. Москва : «РИПОЛ КЛАССИК», 2000.320 с.

7. Burrow C., Sandine W., Elliker P., Speckman C. Characterization of diacetyl negative mutants of Streptococcus diacetilactis. Journal of Dairy Science. 1970. № 2. P. 121-125.

8. Рогова Н.В., Кожухар В.В., Пилипенко Л.М., Кожухар М.В. Технологія виробництва соку березового ферментованого. Збірник наукових пращь ЛНАУ. 2006. Вип. 68. С. 169-173.

9. Рогова Н.В. Вплив температури на термін ферментування і прозорість березового соку. Нові технології і обладнання харчових виробниитв : міжвуз. наук.-практ. семін. (Полтава, 19 квітня 2018 року). ПУЕТ, 2018. C. 21-23.

10. Рогова Н.В., Кожухар В.В., Рибак Г.М. Мінеральний склад ферментованого березового соку та купажів на його основі. Збірник наукових пращь ХДУХТ «Прогресивні техніки та технології харчових виробнищтв». 2007. № 5. С. 177-184.

\section{РоГова Н.В., ВоЛОДЬКо О.В. ХАРЧОВА І БІОЛОГІЧНА ЦІННІСТЬ СОКІВ, ЇХ ДІЯ НА ОРГАНІЗМ ЛЮДИНИ ТА ЗНАЧЕННЯ В ХАРЧУВАННІ}

Стратегія розширення асортименту корисних для здоров'я людей продуктів як пріоритетний напрям розвитку харчової промисловості України зумовлена необхідністю збереження здоров'я населення та поліпшенням якості його життя. Сучасні тенденції розвитку готельно-ресторанного сервісу, туристичних послуг також потребують наявності асортименту біологічно активних продуктів з тривалим терміном зберігання для розробки певних раціонів харчування та дiєm.

Наукове обгрунтування та розробка сучасних технологій виробництва високоякісних низькокалорійних і недорогих продуктів з екологічно чистої вітчизняної сировини та їх впровадження є одним із 
основних напрямів розвитку сучасних галузей харчової науки. При иьому пошук нових ефективних технологій виготовлення сучасних продуктів із рослинної сировини $і$ збереження при иьому ї̈ натуральних властивостей залишається актуальною проблемою.

Головним напрямом розвитку харчової галузі повинна стати розробка на науковій основі $і$ впровадження у виробництво високоякісних і недорогих продуктів харчування. Вихід зі становища - у використанні екологічно чистої сировини, яка вирощується поблизу консервних заводів, а також у застосуванні сучасних технологій ї̈ переробки. Серед продуктів харчування, які володіють захисними функціями, переважне значення мають соки. Хоча соки цілком не вільні від мутагенів, антимутагенна активність є в них переважною. Однак нині немає досить повної інформації про протекторні механізми соків.

За масовістю виробництва та обсягом споживання соки, напої посідають провідне місие в раціоні харчування. Згідно з численними дослідженнями в галузі фізіології харчування найбільш раціональною їх формою є безалкогольні напої, від біохімічного та мікробіологічного складу яких дуже залежить стан здоров'я населення. Тому проблема створення й виробництва безалкогольних напоїв загальнооздоровчого призначення має винятковий вплив на збереження генофонду наиії та розвиток харчової $i$ переробної промисловості.

Ключові слова: технологія, березовий сік, харчування, вітаміни, ароматичні та мінеральні речовини. 